\title{
REKONSTRUKSI KECAKAPAN SOSIAL GURU DALAM PENGEMBANGAN BERBICARA ANAK USIA DINI
}

\author{
Gian Fitria Anggraini \& Ari Sofia \\ e-mail: gian.fitria21@gmail.com \\ PG-PAUD, Jurusan IP FKIP Universitas Lampung \\ JI. Prof. Dr. Soemantri Brojonegoro No. 1
}

\begin{abstract}
Abstrak: Interaksi sosial merupakan pondasi awal bagi anak untuk belajar mengenal lingkungan di sekitarnya. Penelitian ini bermaksud untuk mengkaji pengaruh serta kontribusi kecakapan sosial yang dilihat melalui interaksi antara guru dan anak dalam pengembangan kemampuan bahasa, terutama berbicara usia dini. Penelitian ini dilakukan dari September sampai Oktober 2015. Metode penelitian dilakukan melalui pendekatan kuantitatif, dengan subjek penelitian 30 orang guru PAUD di Bandar Lampung. Pengambilan subjek dilakukan dengan teknik purposive sampling. Data diambil melalui angket dan di analisis dengan regresi linear sederhana. Hasil analisis menunjukkan koefisien regresi sebesar 0,511, dengan nilai signifikansi 0,003 . Hal ini menunjukkan adanya pengaruh yang signifikan antara interaksi sosial terhadap pengembangan kemampuan bicara anak usia dini. Meskipun demikian kontribusi yang diberikan oleh interaksi sosial belum cukup memadai, dan hal ini menandakan perlunya suatu upaya untuk meningkatkan kualitas serta kuantitas interaksi antara guru dan anak.
\end{abstract}

Kata-kata Kunci: interaksi sosial, guru, kemampuan berbicara, literasi, anak usia dini.

\section{TEACHER SOCIAL SKILLS RECONSTRUCTION IN IMPROVING EARLY CHILDHOOD SPEAKING ABILITY}

\begin{abstract}
Social interaction is an early foundation for children to learn recognizing their surrounding environment. This study aimed to examine the relationship and contribution of teacher social skill in interaction between children through language development, especially speaking in early ages. The research was conducted I Bandar Lampung as from September through October 2015. The research subjects were 30 early childhood teachers in Bandar Lampung, which was carried out through purposive sampling technique. The research method was conducted with a quantitative approaches-regression method. The data was collected through a questionnaire and was analyzed by using simple linear regression analysis. The results showed a regression coefficient between variables for 0,511 , with a significance value of 0,003. Interaction performed deeply by teachers on children has a significant influence to the children's speak development. Although the contribution has not been adequate, it indicates that the quality and quantity of interaction between teachers and children needs to be increased.
\end{abstract}

Keywords: teacher social interaction, oral language, literacy, early childhood education.

\section{PENDAHULUAN}

Melakukan interaksi dengan anak memiliki tantangan tersendiri, terutama bagi para guru yang belum mampu memahami perkembangan bahasa terutama berbicara pada anak usia dini secara utuh. Pembelajaran bahasa diawali dengan adanya proses bahasa lisan (oral language) antara anak dengan lingkungannya. Dimulai dengan membunyikan huruf, membaca kata dan kalimat hingga akhirnya dapat berbicara secara utuh. Hal ini sejalan dengan pendapat Niklas \& Schneider (2013) bahwa perkembangan bahasa oral atau lisan merupakan pondasi utama bagi perkembangan literasi dan peningkatan kemampuan membaca anak yang peningkatannya sangat ditentukan oleh pengaruh lingkungan.

Perkembangan berbicara (oral language) merupakan landasan bagi perkembangan literasi dasar seperti bercakap - menyimak, membaca menulis, merasa - menggambarkan, dan berhitung - memperhitungkan (Fauziah, 2008). Kecakapan ini diperlukan untuk mempersiapkan anak-anak usia dini menempuh jenjang pendidikan selanjutnya, yang pada umumnya menuntut mereka untuk siap membaca, menulis dan berhitung. 
Pentingnya pengembangan literasi sejak dini ini perlu didukung oleh keterlibatan orang dewasa di lingkungan sekitar anak, terutama dalam kemampuan berbicara (oral language). Anak membutuhkan suatu role model yang mampu memberikan contoh baik dari segi pengenalan maupun penggunaan huruf, bunyi, kata, angka, dan sebagainya (Vygostky, 1986).

Kualitas membaca atau literasi anak-anak Indonesia masih berada pada urutan ke 29 dari 31 negara di Asia, Afrika, Eropa dan Amerika. Indonesia masih termasuk kategori negara yang pencapaian kegiatan literasinya di bawah 500 , yaitu sebesar 428 atau 4,2 persen di bawah negara Saudi Arabia (Campbell, Kelly, Mullis, Martin, dan Sainsbury, 2001; Mullis et al, 2011). Hal ini menjadi dasar akan pentingnya penanaman serta pengembangan literasi sejak usia dini. Berbagai informasi mengenai pentingnya meningkatkan kemampuan berbahasa atau literasi dasar anak usia dini menjadi polemik tersendiri khususnya dalam pendidikan anak usia dini, karena pada usia ini, anak-anak belum boleh diajarkan membaca dan menulis secara formal. Sementara di sisi lain anak tersebut diharapkan sudah mampu membaca, menulis, dan berhitung setelah lulus dari PAUD atau TK. Hal ini didukung oleh beberapa penelitian yang menyebutkan bahwa anak-anak yang memasuki usia sekolah dasar dengan penguasaan bahasa lisan serta pengetahuan akan kosakata yang kurang, sering mengalami kesulitan pada saat mereka belajar membaca (Hart \& Risley 2000; Cohrssen, Niklas, \& Tayler, 2016).

Kesulitan dalam berbicara merupakan salah satu penghambat bagi penguasaan kosakata (Rohman, 2015). Hambatan ini tentunya secara tidak langsung akan berpengaruh terhadap kemampuan anak dalam menguasai tingkat literasi dasar selanjutnya, baik itu membaca maupun menulis. Penelitian yang dilakukan oleh Scofield dan Behrend (2011) mencoba untuk melihat bagaimana kosakata atau bahasa anak dapat meningkat lewat atensi bersama antara guru dan siswa. Hasil penelitian menemukan bahwa strategi yang disusun oleh guru secara matang serta melibatkan proses interaksi sosial, dapat meningkatkan pembelajaran kosakata (word) pada anak. Hal ini sesuai dengan pendapat Cohrssen et al. (2016) bahwa guru memiliki pengetahuan, dan anak akan belajar tentang suatu pengetahuan tersebut melalui interaksi dengan gurunya. Melalui pertukaran informasi, pelibatan emosi serta atensi bersama pada suatu objek tertentu, secara tidak langsung akan mendorong anak untuk belajar suatu kata baru atau pembelajaran bahasa, terutama berbicara (oral language) secara keseluruhan.

Guru PAUD merupakan fasilitator yang baik bagi anak untuk meningkatkan kemampuan bahasa oral serta mengurangi hambatan-hambatan yang ditemui oleh anak saat belajar berbahasa (Latif, dkk, 2013). Ketika seorang anak memasuki TK atau PAUD, biasanya mereka telah memperoleh banyak struktur bahasa dari bahasa pertama orang tua mereka masing-masing, di sinilah peran guru dalam mengakomodasi seluruh kemampuan siswa yang berbeda-beda sebagai upaya untuk meningkatkan kemampuan bahasa anak-anak. Kuantitas dan kualitas interaksi bahasa antara pendidik dan anakanak sangat mempengaruhi penguasaan kosakata pada anak. Selain itu, berbagai penelitian lain juga menyebutkan bahwa hubungan antara guru dan anak termasuk kemampuan atau kecakapan sosial guru dapat membantu meningkatkan kemampuan berbahasa, kognitif serta keterampilan sosial pada anak (Hart \& Risley 2000; Denisenkova \& Nisskaya, 2016).

Kemampuan guru dalam menyediakan interaksi yang kaya, serta menciptakan lingkungan yang kondusif bagi pembelajaran bahasa anak, menurut Bradley (2011) merupakan langkah yang hendaknya dilakukan dalam manajemen kelas seorang guru preschool atau PAUD. Tanpa adanya kualitas guru yang memadai untuk membantu anak meningkatkan bahasanya, maka pengembangan kemampuan dasar bahasa anak tidak akan optimal. Suryani (2013) dalam opininya terhadap permasalahan PAUD di Indonesia, menyatakan bahwa salah satu kendala yang ditemukan dalam pembangunan PAUD saat ini adalah belum terpenuhinya kualifikasi maupun kompetensi guru secara menyeluruh. Secara akademik, berdasarkan data dan statistik pendidikan Kemendikbud (2014), menunjukkan bahwa persentase guru PAUD yang memiliki ijazah kependidikan lebih tinggi dari S1 adalah sebesar 3,51 persen, sedangkan di bawah S1 sebesar 4,06 persen. Persentase ini menggambarkan bahwa masih banyak guru PAUD yang belum mencapai tingkat pendidikan $\mathrm{S} 1$.

Seorang guru dituntut untuk memiliki seperangkat kemampuan yang dapat 
mengantarkannnya kepada kualitas kinerja agar mampu melaksanakan tugas serta tanggung jawabnya dalam pengajaran maupun pendidikan (Latif, dkk, 2013) Harapannya adalah guru dapat menemukan cara atau strategi terbaik dalam pembelajaran. Oleh sebab itu, guru pun diharapkan untuk memiliki kompetensi yang sesuai dengan kebutuhan pengajarannya di sekolah. Spencer \& Spencer (2011) menguraikan hakekat kompetensi sebagai berikut: "Competency is underlying characteristic of an individual that is causally related to criterion-reference effective and/or superior performance in a job or situation". Kompetensi yang dimiliki oleh seorang guru, tentunya akan berbeda satu sama lain, tergantung pada karakter, pengalaman, serta kondisi dan latar belakang pendidikan masing-masing.

Kualifikasi serta kompetensi yang harus dimiliki oleh guru PAUD, tertuang dalam Peraturan Menteri Pendidikan Nasional Republik Indonesia Nomor 16 Tahun 2007 tentang Standar Kualifikasi Akademik dan Kompetensi Guru. Salah satu kompetensi guru yang mencerminkan terjadinya interaksi diantara guru dan anak didik adalah kompetensi sosial. Kompetensi ini erat kaitannya dengan kemampuan guru baik dalam melakukan komunikasi sosial maupun individual (Latif, dkk, 2013).

Pembelajaran di kelas tidak hanya terjadi melalui proses perencanaan, pelaksanaan dan penilaian secara tersusun saja, namun juga melalui interaksi sosial (Hamalik, 2009). Guru dapat berkomunikasi secara langsung dengan anak didik. Komunikasi secara langsung juga merupakan suatu proses dimana didalamnya terdapat asimilasi nilai-nilai budaya (Fauziah, 2008). Interaksi dapat mendorong anak agar mau aktif berbicara, sehingga secara tidak langsung melalui interaksi anak dapat meningkatkan kemampuan berkomunikasinya. Hal ini juga diperkuat oleh pendapat Surya (2011) yang mengemukakan bahwa kompetensi sosial adalah kemampuan yang diperlukan oleh seseorang agar berhasil dalam berhubungan dengan orang lain serta menjalin hubungan yang baik dengan anak didiknya.

Tugas guru untuk mengayomi, mendidik, membimbing, sebagaimana tertuang dalam kompetensi guru, baik secara profesional, sosial maupun pedagogik, sangat berperan terhadap perkembangan belajar anak. Berkaitan dengan tugas guru, maka potensi keterampilan guru yang baik, setidaknya juga dipengaruhi oleh latar belakang pendidikan serta wawasan calon guru baik secara formal maupun informal (Latif, dkk, 2013). Guru yang teredukasi serta berwawasan, diharapkan memiliki kompetensi yang lebih baik. Salah satu kompetensi yang harus dimiliki oleh guru adalah kompetensi sosial yang berkaitan dengan kemampuan melakukan interaksi baik itu dalam kegiatan belajar mengajar, maupun interaksi secara individu dan kelompok kecil. Melalui interaksi yang kaya bahasa, guru diharapkan memiliki kedekatan hubungan (closeness) yang baik dengan anak (Vygotsky, 1986). Peran guru dalam meningkatkan kemampuan bahasa anak juga disebutkan oleh bukan hanya memberikan informasi mengenai konten atau "isi", namun juga memberikan informasi tentang pembicara itu sendiri, bagaimana pembicara memandang pendengar (atau orang yang diajak berbicara) serta penggambaran atas bentuk hubungan mereka (relationship), yang saat ini kualitasnya masih jarang diperhatikan oleh guru (Halliday, 1993; Fernandez et al, 2015).

Berdasarkan pertimbangan tersebut, maka dalam peningkatan kemampuan literasi anak usia dini akan sangat tergantung pada stimulus, salah satunya melalui interaksi yang terjadi antara anak dengan orang dewasa, salah satunya dengan guru (Schunk, 2012). Oleh karena itu, penelitian ini bertujuan untuk menganalisis dan mengevaluasi bagaimana pengaruh antara kecakapan sosial yang dilihat melalui interaksi guru dan anak, berdasarkan kompetensi sosial guru dalam meningkatkan pengembangan kemampuan berbicara usia dini.

\section{METODE PENELITIAN}

Penelitian ini menggunakan pendekatan kuantitatif, dengan metode regresi linear sederhana untuk mencari pengaruh serta seberapa besar kontribusi antara kecakapan sosial guru PAUD dengan kemampuan pengembangan berbicara (oral language) anak usia dini.

Subjek penelitian adalah guru PAUD di
Bandar Lampung yang berjumlah 30 orang guru. Pengambilan subjek dilakukan melalui teknik purposive sampling dengan karakteristik sebagai berikut: (1) berpendidikan minimal SMA; dan (2) Telah menjadi guru PAUD selama minimal 5 tahun. Penelitian dilaksanakan dari 01 September 2015 sampai 30 Oktober 2015 di Bandar Lampung. 
Pengumpulan data dilakukan melalui instrumen berupa kuesioner yang diukur menggunakan skala likert. Kecakapan sosial dikembangkan dari kompetensi sosial guru PAUD berdasarkan Peraturan Menteri Pendidikan Nasional Republik Indonesia Nomor 16 Tahun 2007 tentang kualifikasi akademik dan kompetensi guru. Kompetensi sosial terdiri dari empat sub kompetensi yaitu (1) bersikap inklusif dan objektif, (2) berkomunikasi secara efektif dan empatik, (3) beradaptasi dalam keanekaragaman sosial budaya, dan (4) membangun komunikasi profesi. Pengembangan kemampuan berbicara (oral language) anak usia dini menggunakan kuesioner yang diadaptasi dari pengembangan bahasa Hart dan Risley (2000), yang meliputi: (i) Kualitas interaksi antara anak dan yang membimbing. Kualitas ini berkaitan dengan kemampuan guru dalam memberikan kedalaman maupun penggalian komunikasi yang interaktif, dua arah dengan anak didik; (ii) Kuantitas antara anak dan yang membimbing. Hal ini berkaitan dengan frekuensi komunikasi yang dilakukan oleh guru dan anak didik; serta (iii) Perbedaan antara isi dan struktur bahasa yang didengar. Unsur yang terakhir berkaitan erat dengan kejelasan serta refleksi yang dilakukan guru pada setiap interaksi yang dilakukannya. Ketiga faktor ini akan berdampak pada bagaimana seorang guru dapat mendengar dan merespon, serta memotivasi anak untuk berbicara dan melakukan interaksi secara aktif.

Instrumen kecakapan sosial guru dan pengembangan kemampuan berbicara anak usia dini masing-masing memiliki 48 dan 54 item pertanyaan. Masing-masing pertanyaan diberikan lima alternatif jawaban, yaitu sangat sesuai (SS), sesuai (S), Ragu-Ragu (R), Kurang Sesuai (KS), dan Tidak Sesuai (TS). Skor untuk pertanyaan positif adalah 1 untuk tidak sesuai (TS), 2 untuk kurang sesuai (KS), 3 untuk ragu-ragu (R), 4 untuk sesuai (S), dan 5 untuk sangat sesuai (SS). Sedangkan untuk pertanyaan negatif jika jawaban guru adalah sangat sesuai (SS) diberi skor 1 , sesuai (S) diberi skor 2, ragu-ragu (R) diberi skor 3 , kurang sesuai (KS) diberi skor 4, dan tidak sesuai (TS) diberi skor 5. Setelah diperoleh data nilai kecakapan sosial dan nilai pengembangan berbicara anak kemudian dimasukkan ke dalam kategori. Adapun kategorisasi ini dihitung berdasarkan kelas interval. Instrumen kecakapan sosial guru dengan skor 178 ke atas dimasukkan ke dalam kategori tinggi dan skor di bawah 112 masuk ke dalam kategori rendah, sedangkan skor antara 113-177 masuk dalam kategori sedang. Instrumen kecakapan sosial guru telah reliabel dengan nilai Cronbach's alpha sebesar 0,929. Sementara itu, untuk instrumen pengembangan berbicara anak usia dini dengan skor di bawah 126 masuk ke dalam kategori rendah dan skor antara 127-199 masuk dalam kategori sedang, sedangkan skor di atas 200 masuk ke dalam kategori tinggi. Instrumen ini telah reliabel dengan nilai alpha cronbach sebesar 0.935 .

Analisis yang digunakan dalam penelitian ini yaitu: (1) Analisis deskriptif. Analisis ini digunakan untuk menjelaskan karakteristik kecapakan sosial guru dan karakteristik pengembangan berbicara anak usis dini. (2) Analisis regresi linear sederhana untuk menganalisis pengaruh kecakapan sosial guru terhadap pengembangan berbicara anak usia dini.

\section{HASIL DAN PEMBAHASAN}

\section{Kecakapan Sosial Guru}

Hasil capaian kecakapan sosial guru menunjukkan rata-rata kemampuan mencapai angka 199 tersaji pada Tabel 1.

Tabel 1. Sebaran Kategori Kecakapan Sosial Guru PAUD

\begin{tabular}{cccc}
\hline \multirow{2}{*}{ No } & \multirow{2}{*}{ Kategori } & \multicolumn{2}{c}{ Total } \\
\cline { 3 - 4 } & & $\mathbf{n}$ & $\%$ \\
\hline 1 & Rendah $(X<112)$ & 0 & 0 \\
2 & Sedang $(113-177)$ & 2 & 6.45 \\
3 & Tinggi $(X>178)$ & 29 & 93.55 \\
\hline & Total & 31 & 100.0 \\
\hline & Rata-rata SD & \multicolumn{2}{c}{$199.00 \pm 16.205$} \\
\hline
\end{tabular}

Berdasarkan kategori kecakapan sosial guru, hampir sebagian besar (93.55\%) guru memiliki kecakapan sosial yang tinggi. Sementara itu, tidak ada $(0 \%)$ guru yang memiliki kecakapan sosial yang rendah. Namun demikian, masih ada sebagian kecil $(6.45 \%)$ guru yang memiiki tingkat kecakapan sosial yang sedang.

\section{Kemampuan Pengembangan Berbicara AUD}

Kemampuan pengembangan berbicara anak usia dini tersaji pada Tabel 2 yang menunjukkan bahwa kemampuan pengembangan berbicara AUD memilki rata-rata mencapai angka 216.74. 
Tabel 2. Sebaran Kategori Pengembangan Kemampuan Berbicara (Oral Language) AUD.

\begin{tabular}{|c|c|c|c|}
\hline \multirow{2}{*}{ No } & \multirow{2}{*}{ Kategori } & \multicolumn{2}{|c|}{ Total } \\
\hline & & $\mathrm{n}$ & $\%$ \\
\hline 1 & Rendah $(X<126)$ & 0 & 0 \\
\hline 2 & Sedang (127-199) & 4 & 12.903 \\
\hline \multirow[t]{3}{*}{3} & Tinggi $\quad(X>200)$ & 27 & 87.097 \\
\hline & Total & 31 & 100.0 \\
\hline & Rata-rata \pm SD & 216 & 9.993 \\
\hline
\end{tabular}

Berdasarkan kategori kemampuan pengembangan berbicara AUD, hampir sebagian besar (87.1\%) berada pada kategori tinggi. Sementara itu, sebagian kecil (12.9\%) guru berada pada kategori sedang. Berdasarkan nilai presentase menunjukkan bahwa pengembangan berbicara hanya memiliki selisih kurang lebih $6 \%$ dengan kecakapan sosial guru pada kategori tinggi maupun sedang. Namun, di antara kedua variabel sama-sama tidak ada $(0 \%)$ guru yang berada pada kategori rendah.

\section{Hasil Uji Pengaruh Kecakapan Sosial Guru} dengan Pengembangan Kemampuan Berbicara

Hasil uji pengaruh kecakapan sosial guru dengan pengembangan kemampuan berbicara menunjukkan angka Adjusted $R$ Square 0.236 yang berarti bahwa model tersebut menjelaskan 23.6 persen pengaruh kecakapan sosial guru terhadap kemampuan pengembangan berbicara anak usia dini, di mana kecakapan sosial guru berpengaruh positif dan signifikan terhadap kualitas kemampuan pengembangan berbicara anak usia dini. Hal ini menandakan bahwa apabila terjadi peningkatan kualitas kecakapan sosial guru maka akan menyebabkan peningkatan kualitas kemampuan pengembangan berbicara anak usia dini. Hasil uji pengaruh kecakapan sosial guru dengan pengembangan kemampuan berbicara secara lengkap tersaji pada Tabel 3.

Tabel 4. Koefisien Regresi Kecakapan Sosial

Guru, Pengembangan Kemampuan Berbicara

$$
\text { AUD }
$$

\begin{tabular}{ccccc}
\hline & \multicolumn{4}{c}{ Koefisien $\beta$} \\
\cline { 2 - 5 } Variabel & $\begin{array}{c}\text { Tidak } \\
\text { terstan- } \\
\text { darisasi }\end{array}$ & $\begin{array}{l}\text { Terstan- } \\
\text { darisasi }\end{array}$ & t & Sig \\
\hline Kecakapan Sosial Guru & 0.631 & 0.511 & 3.204 & 0.003 \\
F & & $10.267^{\text {*** }}$ & \\
R & & 0.551 & \\
Adjusted R square & & 0.236 & \\
\hline
\end{tabular}

\section{Pembahasan}

Penelitian ini mengangkat pentingnya kecakapan sosial dimiliki oleh guru untuk meningkatkan kualitas interaksi yang dilakukannya terutama dalam pengembangan berbicara anak usia dini. Menurut Bradley dan Reinking (2011), seorang guru dapat mengembangkan hubungan atau interaksi dengan muridnya dalam rangka menciptakan lingkungan yang kondusif bagi peningkatan pengembangan bahasa anak.

Proses pemahaman anak terhadap suatu fenomena atau informasi baru dapat berjalan secara alami, seperti melalui kegiatan observasi atau eksperimen, eksplorasi dengan melihat, merasakan, menyentuh, meraba, melakukan, maupun kegiatan yang bersifat langsung lainnya (Vygotsky, 1986; Fauziah, 2008). Tidak hanya melalui pengalaman kegiatan yang dialaminya sendiri, pemahaman yang dimiliki oleh seorang anak juga muncul karena adanya proses belajar atau pembelajaran yang sengaja dilakukan oleh orang dewasa dilingkungannya (Fauziah, 2008). Pembelajaran yang dilakukan dengan sengaja inilah yang diharapkan mampu menambah wawasan serta pengalaman anak pada tingkat yang lebih tinggi lagi. Oleh sebab itu, meskipun anak telah memiliki pemahaman awal atau dasar mengenai suatu fenomena, namun proses pembinaan maupun bimbingan tetap dibutuhkan untuk memperluas jangkauan cakrawala berpikir anak. Pada setiap titik perkembangan, anak-anak membutuhkan bantuan orang dewasa untuk membantunya dalam membentuk serta mengkonstruksi lingkungannya sendiri (Vygotsky, 1986; Fauziah, 2008; Musthafa, 2008).

Pada tahap perkembangan kognitif anak yang salah satunya dikemukakan oleh Vygotsky (1986) disebutkan bahwa anak mengelola suatu informasi melalui proses akomodasi dan asimilasi, dimana kedua proses ini melibatkan suatu interaksi sosial yang memperkuat pembangunan suatu pengetahuan maupun pemahaman, yang disebut sebagai proses scaffolding atau perambatan. Proses scaffolding ini tentunya dapat terjadi dalam kegiatan pembelajaran di sekolah melalui peran guru (Musthafa, 2008). Berdasarkan pemahaman ini dapat kita simpulkan bahwa proses Scaffolding yang didalamnya termuat interaksi sosial, merupakan salah satu hal penting dalam mendukung kemampuan anak membangun 
konstruksi atau landasan berpikir. Dengan kata lain, interaksi sosial yang dilakukan dalam pembelajaran berkontribusi terhadap proses pembentukan pemahaman anak. Vygotsky (1986) menyebutkan pentingnya pembelajaran yang berbasis budaya serta interaksi sosial, karena melalui interaksi inilah anak belajar mempersepsikan serta mengkonstruksi lingkungannya. Semakin sering anak diajak berinteraksi, maka intelektualitasnya akan semakin berkembang, dan inilah yang akan menjadi dasar berkembangnya keterampilan lain, seperti sosial dan juga bahasa (Johnston, 2004; Fauziah, 2008). Artinya, peran scaffolding atau interaksi sosial, tidak hanya dalam fungsi rekonstruksi kognitif saja, namun juga sebagai dasar berkembangnya keterampilan lain.

Bradley dan Reinking (2011) menemukan bahwa pembelajaran literacy (keaksaraan) yang dilakukan melalui kegiatan pengayaan bahasa serta dengan melibatkan anak pada suatu lingkungan yang kaya bahasa akan membantu mereka meningkatkan perkembangan bahasanya, terutama menjelang usia lima tahun, karena masa usia ini adalah yang paling baik untuk mempersiapkan anak sebelum mereka belajar membaca. Salah satu peran guru yang tentunya dapat mendukung kemajuan belajar anak adalah dengan memberikannya suatu pengalaman belajar yang kaya dan sesuai dengan kebutuhan, oleh sebab itu guru pendidikan anak usia dini memiliki posisi yang baik dalam meningkatkan keterampilan berbahasa (Schwartz 1996; Hamre, Hatfield, Pianta, \& Jamil, 2014).

Pentingnya peran guru dalam meningkatkan kemampuan berbahasa anak banyak disebutkan dalam beberapa literatur, salah satu literatur menyebutkan bahwa bahasa tidak hanya mengandung konten atau "isi", namun juga memberikan informasi tentang pembicara atau penyampai pesan itu sendiri, bagaimana pembicara memandang pendengar (atau orang yang diajak berbicara) serta penggambaran atas bentuk hubungan mereka (relationship) yang disebut sebagai dimensi ideasional dan internalisional (Halliday, 1993; Fernandez et al, 2015). Hal ini menunjukkan bahwa apa yang dikatakan, baik itu respon maupun ucapan verbal guru pada anak, secara tidak langsung dapat menggambarkan kualitas hubungan guru dan anak, serta secara signifikan akan memberi dampak pada kualitas percakapan mereka.
Kesinambungan antara peran guru dalam mendorong terciptanya lingkungan pembelajaran yang kaya akan interaksi, baik secara sosial maupun budaya serta keahlian yang dimiliki seorang guru dalam menciptakan kegiatan belajar yang interaktif, kaya akan sumber literasi, serta memahami perbedaan yang dimiliki oleh seorang anak, tentunya akan sangat membantu anak dalam memahami dan mengenal lingkungannya sendiri, serta mengenal bahasa lingkungannya (Fauziah, 2008; Musthafa, 2008). Hal ini juga ditekankan dalam penelitian Longobardi et al (2015) bahwa interaksi antara guru dan anak memiliki potensi dalam mengembangkan kemampuan berbahasa anak usia dini.

Penelitian Scofield dan Bahrain (2011) juga menemukan hal yang sama, bahwa saat guru memiliki pengetahuan, maka anak akan belajar tentang suatu pengetahuan tersebut melalui interaksi dengan gurunya. Adanya pertukaran informasi melalui atensi bersama pada suatu objek tertentu, secara tidak langsung akan mendorong anak untuk belajar suatu kata baru atau pembelajaran bahasa secara keseluruhan (Scofield dan Behrend, 2011). Peran interaksi sosial guru tentunya tidak dapat dipisahkan, terutama dalam membangun dan menciptakan lingkungan belajar yang komunikatif, atraktif, dan merangsang anak untuk selalu ikut aktif dalam aktifitas yang dilakukan bersama.

Berdasarkan hasil juga ditemukan bahwa, meskipun performa interaksi serta pengembangan kemampuan berbicara tergolong tinggi, namun tidak terlalu banyak kontribusi yang dapat diberikan oleh interaksi sosial guru terhadap pengembangan berbicara anak usia dini. Hal ini bisa menjadi indikator belum optimalnya peran guru terutama dalam mengembangkan kemampuan berbicara anak. Banyak faktor yang dapat mempengaruhi kualitas interaksi sosial guru, salah satunya adalah pengalaman guru dalam melakukan interaksi yang berkualitas maupun yang mendalam pada aktifitas pembelajaran yang dilakukannya (Bradley dan Reinking, 2011). Kurangnya pengalaman ini tentunya selain karena faktor internal juga dapat disebabkan oleh terbatasnya faktor eksternal seperti penunjang yang dapat membantu guru dalam meningkatkan keterampilan sosial, misalnya pelatihan maupun pendidikan (Mulyasa, 2012). Latar belakang guru yang belum memadai secara akademik maupun profesional, juga sedikitnya mempengaruhi penguasaan kompetensi-kompetensi 
yang sejatinya dimiliki oleh guru, dan salah satunya adalah kompetensi sosial.

Kualitas interaksi sosial akan berdampak pada proses pengalaman dan juga penukaran informasi yang terjadi dalam interaksi tersebut. Longobardi (2015) dalam penelitiannya juga mengemukakan bahwa kualitas sosial, baik itu cara berkomunikasi maupun pendekatan interaksi yang dilakukan oleh seorang guru, akan sangat mempengaruhi kualitas pengalaman belajar bahasa yang akan dialami oleh seorang anak. Penelitian lain yang dilakukan oleh Greenstock, Louise, dan Wright (2011) mengemukakan bahwa konflik yang sering terjadi diantara guru mengenai penggunaan strategi pembelajaran bahasa adalah akibat adanya perbedaan pemikiran, kepercayaan serta motif para guru dan jika tidak terjadi kolaborasi yang seimbang antara para guru ini, secara tidak langsung akan berpengaruh terhadap proses pembelajaran bahasa anak. Hal ini menunjukkan bahwa kualitas interaksi sosial dalam diri seorang guru juga akan ditentukan oleh persepsi, kualitas pribadi serta keaktifannya untuk bekerja sama dan saling memberikan refleksi serta penguatan dalam pengembangan bahasa anak (Barrat dan Rohl, 2000; Scott-Little et al., 2011).

Kecakapan sosial yang dimiliki oleh guru berperan dalam kemampuannya mengembangkan potensi anak, baik itu dari segi pembelajaran maupun manajemen kelas, dan salah satunya adalah pengembangan kemampuan berbicara (Hamre, Hatfield, Pianta, \& Jamil, 2014). Pengembangan kemampuan berbicara memiliki indikator sebagai berikut: (i) kualitas Interaksi antara anak didik dan guru; (ii) kuantitas Interaksi antara anak didik dan guru; (iii) perbedaan antara isi serta struktur bahasa yang didengar oleh anak (Hart dan Risley 2000). Kualitas interaksi akan saling mempengaruhi satu sama lain dengan kuantitas interaksi. Semakin sering seorang guru melakukan interaksi yang mendalam dengan anak, maka secara tidak langsung hal ini akan meningkatkan kualitas dan kuantitas kemampuan berbicara anak.

Penelitian yang dilakukan oleh Oates et.al (2011), mengungkapkan bahwa saat anak belajar untuk ikut serta dalam aktifitas kelas dan juga saat guru mencoba untuk mengatur perilakunya dalam kelas secara tidak langsung akan memunculkan kemampuan literacy pada anak secara bertahap. Artinya semakin sering guru dan anak terlibat dalam aktivitas atau kegiatan literasi maka kemampuan literasi anak akan semakin berkembang. Kualitas interaksi ini juga tentunya akan mempengaruhi konten atau isi dalam pembelajaran literasi, semakin tinggi kelihaian atau keterampilan serta pengalaman literasi dalam suatu kelas, maka kualitas bahan materi literasi yang terjadi pun akan semakin kaya (Whitebread, 2003). Salah satu pengayaan bahan materi literasi yang dapat mengayakan pengalaman literasi diungkapkan dalam penelitian Kim et al (2011) yang menyatakan bahwa joint book reading dapat memberikan kesempatan bagi anak untuk mendiskusikan apa yang telah mereka baca dan merangkumnya lewat retelling. Kegiatan retelling (menceritakan kembali), secara tidak langsung dapat menambah wawasan dan pengalaman kelas dalam mendukung situasi literasi yang kaya akan makna. Hal ini membuktikan bahwa antara kualitas, kuantitas dan konten materi pengembangan bahasa anak usia dini saling berpengaruh dan berkaitan satu sama lain.

Secara garis besar, dapat kita simpulkan bahwa, proses interaksi akan mempengaruhi proses pembentukan pengetahuan atau konstruksi lingkungan pada anak. Interaksi yang dilakukan oleh orang dewasa tentunya sangat berpengaruh terhadap pemaknaan bahasa lingkungan yang dibentuk anak. Semakin sering interaksi ini terjadi, maka akan tercipta kualitas, baik itu dari segi pendekatan secara sosial, maupun seacara konten, yang dapat mempengaruhi kualitas pengembangan bahasa anak. Kualitas interaksi tentunya juga dipengaruhi oleh banyak faktor, seperti latar belakang budaya, sosial, sejarah, nilai-nilai, dan sebagainya (Fauziah, 2008). Pengalaman sosial pribadi guru akan mempengaruhi kualitas interaksi yang dilakukannya dengan anak usia dini. Oleh sebab itu, diperlukan pembinaan pada diri guru untuk mengembangkan kemampuan berinteraksi atau kecapakan sosial sehingga kemampuan interaksi ini dapat digunakan secara maksimal dalam pengembangan bahasa ekspresif anak usia dini.

\section{PENUTUP}

\section{Kesimpulan}

Berdasarkan hasil penelitian dapat disimpulkan bahwa, terdapat pengaruh yang signifikan dengan nilai $\mathrm{R}$ sebesar 0.511 , antara 
kecakapan sosial guru dengan pengembangan kemampuan berbicara (oral language) anak usia dini. Sementara itu gambaran umum kecakapan sosial dan pengembangan kemampuan berbicara anak mengarah pada kategori tinggi, meskipun demikian kontribusi kecakapan sosial guru terhadap pengembangan kemampuan berbicara anak usia dini hanya sebesar 23,6 persen. Hal ini mengindikasikan bahwa pengalaman guru untuk melakukan interaksi dengan anak, terutama dalam mengembangkan kemampuan berbicara belum cukup memadai.

Kualitas interaksi akan dipengaruhi oleh kuantitas interaksi. Semakin sering guru melakukan interaksi mendalam dengan anak, maka kualitas interaksi akan tercipta dengan maksimal (Vygostky, 1986). Hal ini menunjukkan bahwa semakin banyak pengalaman guru dalam melakukan interaksi dengan anak, maka secara tidak langsung dapat mempengaruhi kualitas interaksi itu sendiri. Berdasarkan hasil penelitian dapat kita tekankan bahwa kualitas interaksi sosial tentunya akan berdampak jika bukan hanya sekedar dipahami dan dimiliki saja oleh guru namun benar-benar dapat mempengaruhi proses pengembangan kemampuan berbicara anak usia dini secara utuh.

Sementara itu, hasil penelitian ini masih memerlukan pendukung lain yang dapat dilakukan melalui pendekatan penelitian yang lebih mendalam untuk mengkaji dan menggambarkan interaksi sosial guru secara keseluruhan terutama dalam pengembangan bahasa. Selain itu latar belakang pendidikan responden serta usia juga menjadi salah satu perhatian dalam penelitian, karena setidaknya hal itu juga dapat mempengaruhi kontribusi kecakapan sosial terhadap pengembangan kemampuan berbicara anak usia dini. Penelitian ini setidaknya dapat memberikan gambaran secara umum bahwa kecakapan sosial yang dimiliki oleh guru dapat berpengaruh terhadap pola interaksi, yang nantinya akan sangat membantu dalam pengembangan potensi dan keterampilan anak usia dini.

\section{Saran}

Adapun saran yang dapat diberikan pada guru PAUD terkait kecakapan sosial dalam melalukan interaksi dengan anak diantaranya adalah: (i) Guru dapat meluangkan waktu untuk terus melakukan interaksi dengan anak dalam berbagai kesempatan; (ii) Guru dapat memulai untuk melakukan interaksi yang lebih mendalam dengan anak didik; (iii) Guru dapat memulai untuk lebih peka dan merespon setiap apa yang anak katakan, dan menjadikannya sebagai anak tangga bagi penguasaan keterampilan anak yang lebih tinggi; (iv) Guru dapat mulai untuk menghargai setiap perbedaan yang ada pada diri anak; (v) Guru terus melakukan evaluasi secara berkesinambungan untuk melihat grafik perkembangan bahasa anak, serta untuk mengevaluasi kualitas dan konten pengembangan bahasa terutama keterampilan berbicara setiap anak.

Bagi lembaga pendidikan anak usia dini, saran yang bisa diberikan adalah sebagai berikut: (i) pihak lembaga dapat membantu dengan melakukan observasi penilaian kinerja maupun kompetensi sosial guru PAUD terutama dalam melakukan interaksi sosial di setiap pembelajaran; (ii) pihak lembaga dapat membantu dengan memberikan masukan, melalui kegiatan yang hampir mirip dengan "lesson study" dimana setiap guru memiliki kesempatan untuk diberikan feedback terutama dalam keterampilannya melakukan interaksi mendalam dengan anak usia dini; (iii) pihak lembaga dapat membantu dengan memberikan pelatihan atau pengembangan diri yang berkaitan dengan peningkatan kompetensi sosial guru PAUD agar secara tidak langsung pemahaman, wawasan, pengalaman, serta keterampilannya lebih berkembang dan tentunya dapat mendukung proses pembelajaran terutama pengembangan kemampuan berbicara (oral language) anak usia dini.

\section{DAFTAR PUSTAKA}

Barratt., \& Rohl. (2000). Literacy learning in the early years. Australia: Allen \& Unwin.

Bradley, B. A. M \& Reinking, D. (2011). A formative experiment to enhance teacher-child language interactions in a preschool classroom. Journal of Early Childhood Literacy, 2011 11:362. doi: $10.1177 / 1468798411410802$.
Campbell, Kelly, Mullis, Martin, \& Sainsbury. (2001). Framework and spesifications for PIRLS assesment. USA: International Association for the Evaluation of Educational Achievement (IEA).

Denisenkova, N. S., \& Nisskaya, A. K. (2016). The role of teacher-child interaction in promoting 
peer communication. Psychology in Russia: State of the Art, 9(3), 173-187. https://doi. org/10.11621/pir.2016.0312.

Fauziah, D. U. (2008). Keindahan belajar dalam perspektif pedagogi. Jakarta: Cindy Grafika.

Fernandez. (2015). Teacher-child interaction training: A pilot study with random assignment. Behaviour Therapy, 46, 463-477.

Greenstock, L., \& Wright, J. (2011). Collaborative implementation working together when using graphic symbols. Journal Child Language Teaching and Therapy. 2011 27: 331. doi: $10.1177 / 0265659010396778$

Halliday, M. A. K. (1993). Towards a language-based theory of learning. USA: Linguistics and Education Press.

Hamalik. (2009). Strategi belajar mengajar berdasarkan CBSA. Bandung: Sinar Baru Albisnindo.

Hamre, B., Hatfield, B., Pianta, R., \& Jamil, F. (2014). Evidence for general and domain-specific elements of teacher-child interactions: associations with preschool children's development. Child Development, 85(3), 1257-1274. https://doi.org/10.1111/ cdev.12184.

Hart, B \& Risley, T. (1995). Meaningful differences in the everyday experiences of young american children. Baltimore, MD: Paul H. Brookes.

Johnston. (2004). Choice words: How our language affects children learning. US: Stanehouse Publisher.

Kemendikbud. (2014). Statistik pendidikan anak usia dini. Jakarta: Setjen, Kemdikbud.

Kim et al. (2011). The relationship between children's spontaneous utterance during joint book reading and their feelings. Journal of Early Childhood Literacy, 2011 11: 402. doi: $10.1177 / 1468798411409301$

Latif, dkk. (2013). Orientasi baru pendidikan anak usia dini: Teori dan aplikasi. Jakarta: Kencana.

Levitt \& Owl. (2013). Effects of literacy environmens on the reading attitudes, behaviours, and values of veteran teacher. Learning Environment Res Journal. New York: Spinger.

Longobardi. (2015). Language and social competence in typically developing children and late talkers between 18 and 35 months aged. Early Child Development and Care Journal. doi: 10.1080/03004430.2015.1039529.
Mullis et al. (2011). PIRLS 2011 international result in reading. USA: TIMSS and PIRLS.

Mulyasa. (2012). Manajemen PAUD. Bandung: Rosdakarya.

Musthafa. (2008). Dari literasi dini ke literasi teknologi. Jakarta: New Concept English Education C.

Oates et al. (2011). Effective behavior management in preschool classrooms and children's task orientation: enhancing emergent literacy and language development. Journal of Early Childhood Research Quarterly. doi: 10.1016/j. ecresq.2011.02.003.

Rohman. (2015). Perkembangan bahasa pada anak usia dini. Refika: Bandung.

Schwartz et al. (1996). Examining the use of recommended language intervention practices in early childhood special education. Topics in Early Childhood Special Education 16(2): 251-273.

Schunk. (2012). Learning theories: An educational perspective. Teori-teori pembelajaran: Perspektif pendidikan. Yogyakarta: Pustaka Pelajar.

Scofield, J \& Behrend, D.A (2011). Clarifying the role of joint attention in early word learning. Journal of First Language. doi: 10.1177/0142723710395423.

Scott-Little, C., La Paro, K. M., Thomason, A. C., Pianta, R. C., Hamre, B., Downer, J., Howes, C. (2011). Implementation of a course focused on language and literacy within teacherchild interactions: Instructor and student perspectives across three institutions of higher education. Journal of Early Childhood Teacher Education, 32(3), 200-224. https:// doi.org/10.1080/10901027.2011.594489 .

Spencer, L.M \& Spencer. (2011). Competence at work: Models for superior performance. USA: John Wiley \& Sons. Inc.

Surya, M. (2011). Psikologi pembelajaran dan pengajaran. Bandung: Yayasan Bhakti Winaya.

Suryani. (2013). Pakar pendidikan usia dini UNJ seminar di Jombang. Diakses dari http:// www.lensaindonesia.com/2013/06/22/pakarpendidikan-usia-dini-unj-seminar-di-jombang. html pada tanggal 12 Maret 2016.

Vygotsky, L. (1986). Thought and language. Cambridge, MA: MIT Press. 
Rekonstruksi Kecakapan Sosial ...

Whitebread, D. (2003). Teaching and learning in the early years. New York: Routledge. 